\title{
Experimental Investigation on the Influence of Dust on PV Panel Performance and Its Surface Temperature
}

\author{
Abhishek Kumar Tripathi ${ }^{1, a, *}$, Ch.S.N. Murthy ${ }^{1, b}$ and M. Aruna ${ }^{2, c}$ \\ ${ }^{l}$ Department of Mining Engineering, A.K.S. University, Satna, M.P., India \\ ${ }^{2}$ Department of Mining Engineering, National Institute of Technology Karanataka, Surathkal, India \\ a.abhinitrkl12@gmail.com,b.chsn58@gmail.com, c.arunamangalpady@gmail.com \\ *abhinitrkl12@gmail.com
}

Keywords: Dust, photovoltaic, power output, short circuit current, open circuit voltage

\begin{abstract}
The energy demand and present climate change are critically driving all countries of the world towards solar energy as a sustainable renewable and environment friendly source of energy. Solar photovoltaic (PV) is required to convert solar energy into electrical energy and its performance is primarily dictated by its surrounding environmental parameters, such as dust, temperature, wind speed and humidity. The deposition of dust on the PV module surface procreates less impact on an open circuit voltage, whereas it procreates significant impacts on the short circuit current and maximum power output of PV panel. This study shows that the reduction of short circuit current and output power of PV module are 0 to $30.56 \%$ and 0 to $40 \%$, respectivel,y with the deposition of the dust from 0 to $11 \mathrm{gm}$ on the module surface. Moreover, this study also demonstrates that the surface temperature of the dusty panel is higher $(12.32 \%)$ than the clean panel under the same working conditions.
\end{abstract}

\section{Introduction}

Both economic growth and industrialization are dependent on the availability of energy resources, but the fast depletion and acute shortage of energy resources have put the world energy consumers to look towards the alternative, sustainable and renewable energy sources [1], [2]. Electricity is the secondary form of energy, which derived from the primary form of energy, such as fossil fuels, nuclear and renewable energy. The usage of renewable energy is not only promoting the green energy in the environment, but at the same time it full-fill the demand of energy consumption of world energy consumers [3]. There are various kinds of renewable energy, such as hydro, geothermal, biomass, wind and solar, among these, solar energy getting more and more attention in the last decade because of its huge advantages, like availability of raw material, no emission of any pollutant, can be used in remote areas, do not generate noise problem, the panels are easy to install and encouragement by the government in the form of subsidy. Therefore, solar energy could be considered as an appropriate choice of electricity generation in the present energy scenario [4]. The photovoltaic (PV) device is a part of solar energy system which is able to generate electrical energy directly from the incoming solar radiation (solar energy) [5]. Whenever, sunlight strikes on the PV 
cell surface, which is made up of silicon type semiconductors, it generates electron-hole pairs inside the semiconductor material. This generation of electron hole pairs inside the semiconductor material is the main cause of electrical power generation in solar photovoltaic system.

\section{Performance of PV Panel}

The various environmental parameters, like solar radiation, ambient temperature, humidity, wind speed and dust affect the performance of PV panel. Among these parameters dust affects the PV panel performance significantly. Dust blocks and reflects the incoming sunlight on the panel surface and this is the main cause of performance degradation [6], [7]. In a study, it was found that due to the sand dust deposition on PV panel surface, the decrement in short circuit current (Isc) and maximum power output (Pmax) are respectively $40 \%$ and 34\% [8]. Similarly, in another study, it was shown that the decrement in PV panel efficiency was $10 \%, 16 \%$ and $20 \%$ respectively for 12.5 $\mathrm{g} / \mathrm{m} 2,25 \mathrm{~g} / \mathrm{m} 2$ and $37.5 \mathrm{~g} / \mathrm{m} 2$ dust deposition on its surface [9]. One more study indicated that the dust significantly affects the optical transmittance of PV panel, which reduces the electrical parameters like, Isc and Pmax up to $2.23 \%$ and $7.98 \%$, respectively [10]. Further, one more study shown that the reduction Isc and Pmax of PV panel was up to $28.6 \%$ and $30.6 \%$ after 12 days of its exposure into the atmospheric condition [11].

The surface temperature of PV panel is another vital parameter which affects its performance. The electrical parameters of PV panel, such as open circuit voltage (Voc), fill factor (FF) and efficiency decreases with the increase in its surface temperature. Although, the increment in Isc is very small with the increase in surface temperature. Thus, the performance of PV panel decreases with the increases in its surface temperature [12-14]. Another study reported a $10.3 \%$ improvement in the panel energy due to the reduction in its surface temperature by $22^{\circ} \mathrm{C}$ [15]. One more study shows that, the reduction in Voc was $0.45 \%$ and the increase in Isc was $0.09 \%$ with every $1 \mathrm{~K}$ increase in the panel temperature [16]. Since, the deposition of dust on the panel surface and its surface temperature are the two important parameters that affect the panel performance in an open atmosphere. Therefore, in this paper an attempt has been made to investigate the effect of dust deposition on the PV panel performance and its surface temperature.

\section{Effect of Dust on PV Panel Performance}

An indoor experimental set-up shown in Figure 1, was used to study the effect of dust on PV panel performance using $20 \mathrm{~W}$ poly-crystalline PV panel. The technical specifications of the panel are presented in Table 1. Iron ore dust pollutants of size less than $75 \mu$ were used in the present study. This dust pollutant was distributed on the panel surface in three stages, i.e. $5 \mathrm{gm}, 8 \mathrm{gm}$ and $11 \mathrm{gm}$ in mass. For every trial of these stages i.e., dust distribution, the electrical responses of PV module, such as current, voltage and power were recorded. During this study, a constant solar radiation of $567 \mathrm{~W} / \mathrm{m} 2$ was maintained on the panel surface. The rheostat of rating $320 \mathrm{ohm}$ was used as an output load for PV panel which is connected through the ammeter and a voltmeter for the measurements of output current and voltage respectively. Table 2, represents the measured values of Isc, Voc and Pmax of PV panel due to the iron ore deposition on its surface. 


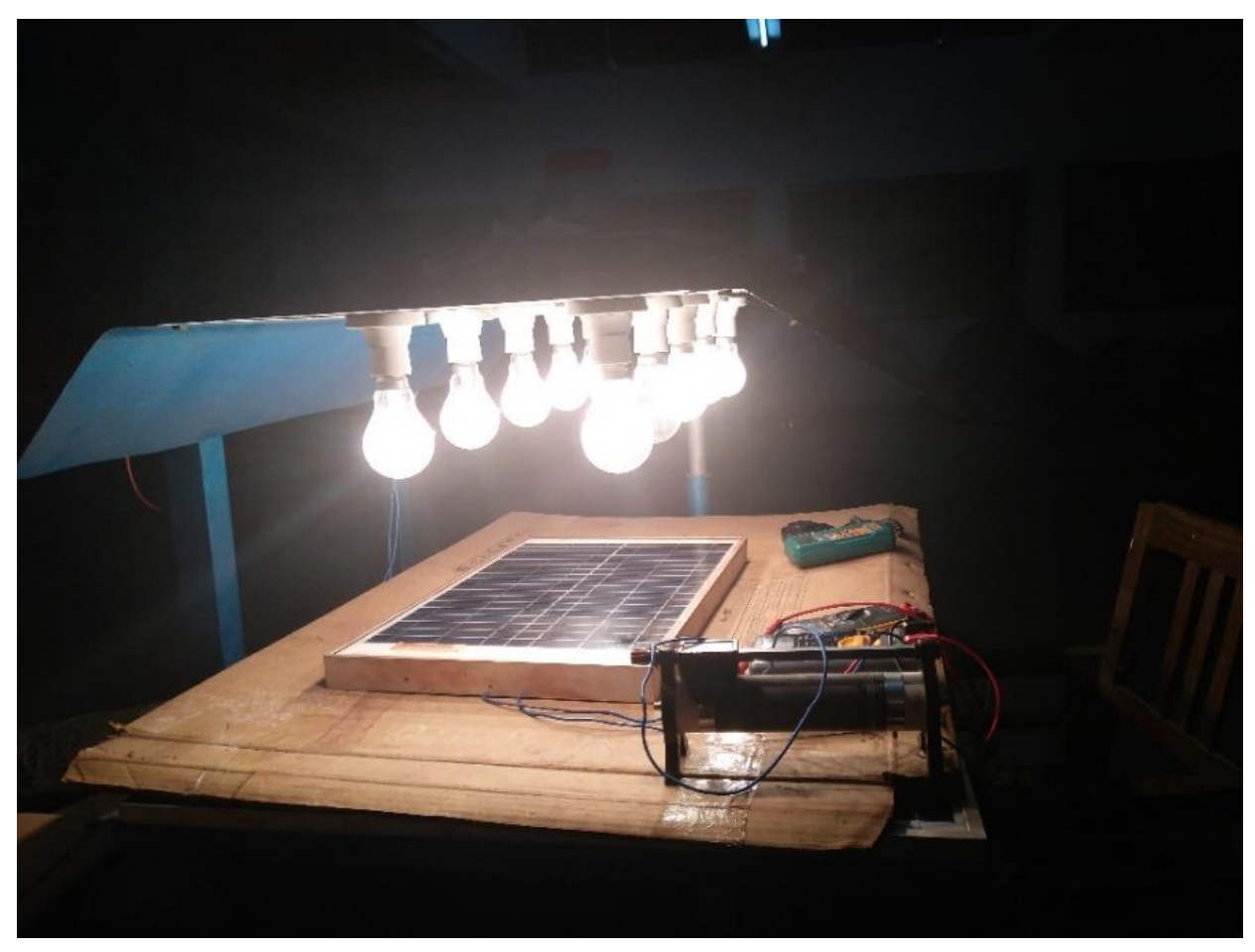

Figure 1: Experimental set-up

Table 1: Technical specifications of $20 \mathrm{~W}$ ploy crystalline PV panel

\begin{tabular}{|c|c|c|}
\hline Sl. No & Parameter & Ratings \\
\hline 1 & Open circuit voltage & $21.50 \mathrm{volt}$ \\
\hline 2 & Short circuit current & $1.28 \mathrm{amp}$ \\
\hline 3 & Maximum voltage & $17.00 \mathrm{volt}$ \\
\hline 4 & Maximum Power & $20 \mathrm{watt}$ \\
\hline 5 & Maximum current & $1.2 \mathrm{amp}$ \\
\hline 6 & Fill Factor & 0.727 \\
\hline 7 & Normal operating cell temperature & $(47 \pm 2)^{\circ} \mathrm{C}$ \\
\hline
\end{tabular}


Table 2. Measured electrical parameters

\begin{tabular}{|c|c|c|c|}
\hline $\begin{array}{c}\text { Mass } \\
\text { deposition } \\
(\mathrm{gm})\end{array}$ & $\begin{array}{c}\text { Short circuit } \\
\text { current } \\
(\mathrm{amp})\end{array}$ & $\begin{array}{c}\text { Open circuit } \\
\text { voltage } \\
(\text { volt })\end{array}$ & $\begin{array}{c}\text { Maximum power } \\
\text { output } \\
\text { (watt) }\end{array}$ \\
\hline 0 & 0.36 & 18.40 & 4.37 \\
\hline 5 & 0.31 & 18.20 & 3.35 \\
\hline 8 & 0.27 & 18.00 & 2.81 \\
\hline 11 & 0.25 & 17.80 & 2.62 \\
\hline
\end{tabular}

Based on the measured electrical responses of the PV panel its electrical characteristics, such as current-voltage and power-voltage characteristics were plotted which are shown in Figure 2 and Figure 3. Similarly, the reduction in Isc, Voc and Pmax were calculated, which are presented in Table 3. The results obtained in Table 3 indicates that a significant reduction in Isc and Pm due to the deposition of dust on its surface, whereas the reduction is meagre in case of Voc. This is because of the direct dependency of Isc and Pmax on the solar radiation falling on the panel. On the other hand, Voc of the panel is proportional to the logarithmic of the solar radiation falling on its surface. Therefore, the reduction in Voc (3.26\%) due to the reduction in solar radiation is not much significant compared to of Isc (30.54\%) and Pmax (40.04\%) of PV panel.

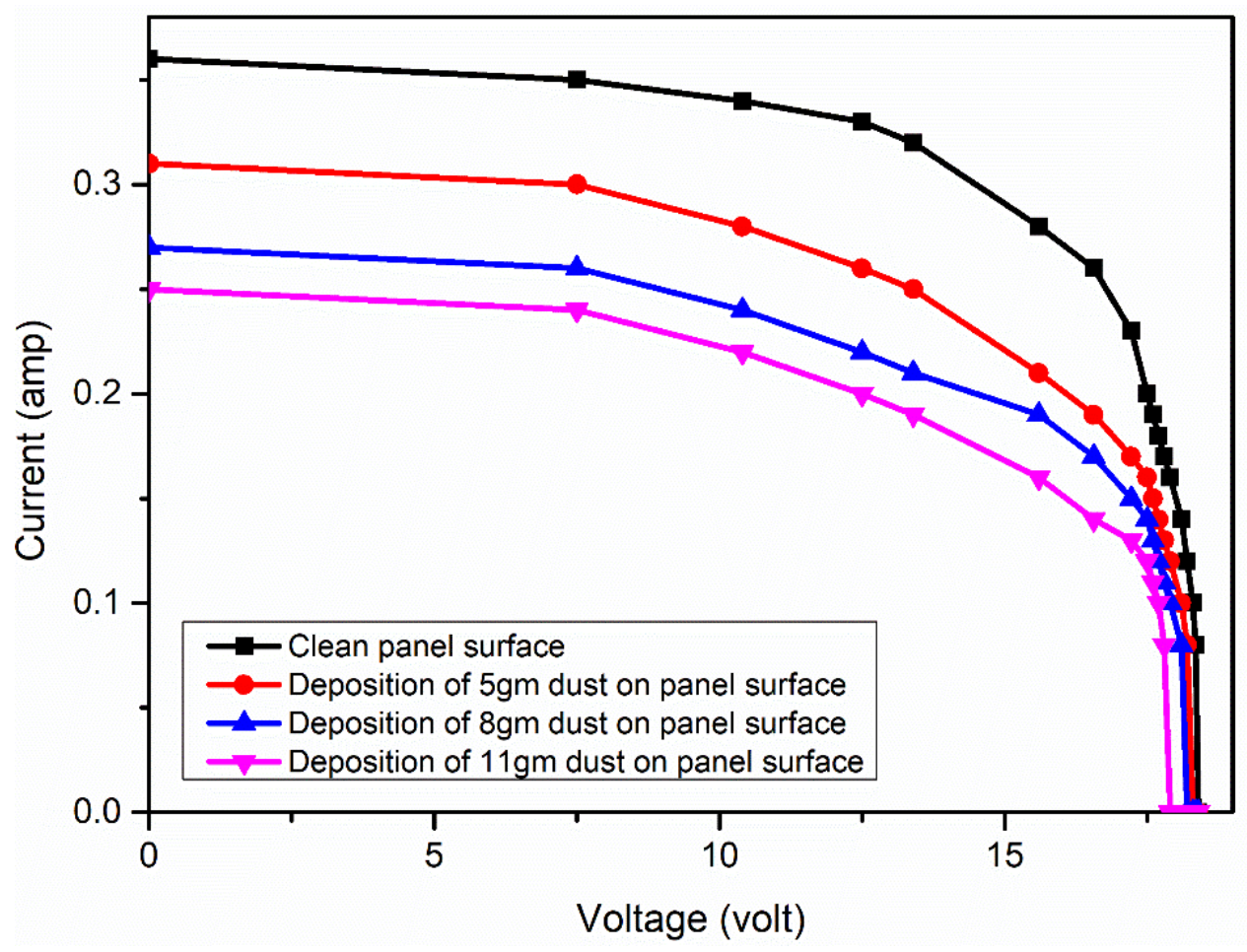

Figure 2: I-V curve of PV panel 


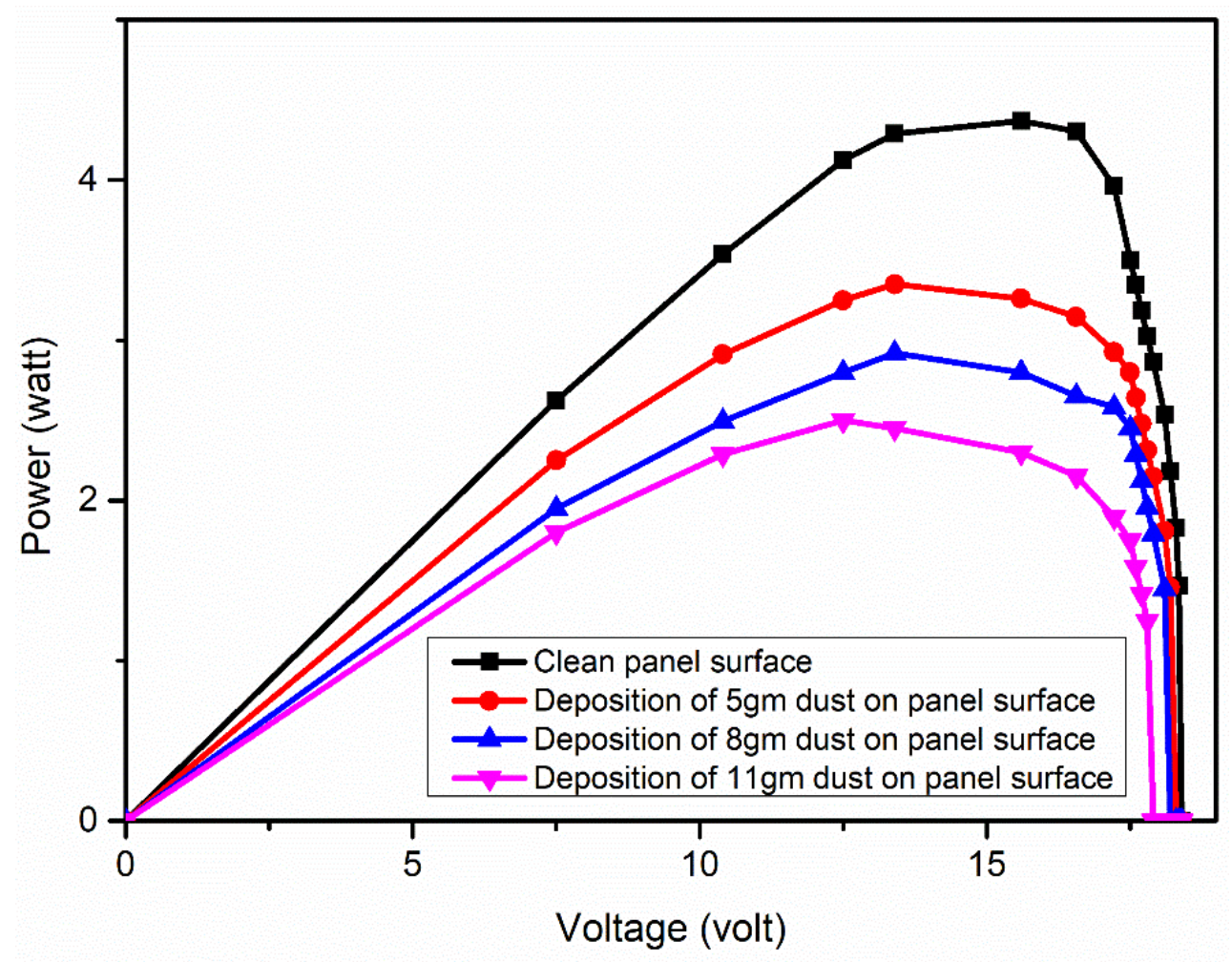

Figure 3: P-V curve of PV panel

Table 3: Effect of Iron ore dust on the panel performance

\begin{tabular}{|c|c|c|c|}
\hline $\begin{array}{c}\text { Mass } \\
\text { deposition } \\
(\mathrm{gm})\end{array}$ & $\begin{array}{c}\text { Reduction in short } \\
\text { circuit current } \\
(\%)\end{array}$ & $\begin{array}{c}\text { Reduction in open } \\
\text { circuit voltage } \\
(\%)\end{array}$ & $\begin{array}{c}\text { Reduction in } \\
\text { maximum power output } \\
(\%)\end{array}$ \\
\hline 5 & 13.88 & 1.08 & 23.34 \\
\hline 8 & 25.00 & 2.18 & 35.69 \\
\hline 11 & 30.56 & 3.26 & 40.04 \\
\hline
\end{tabular}

\section{Effect of Dust on PV Panel Surface Temperature}

To study the temperature difference between clean and dusty panel, under the same environmental conditions, a laboratory study was performed using two identical $20 \mathrm{~W}$ polycrystalline PV panels. Both the panels were placed under a constant solar radiation of $1024 \mathrm{~W} / \mathrm{m} 2$, which was generated with the help of solar simulators (incandescent bulbs). On one panel iron ore dust of $3 \mathrm{gm}$ in mass was spread with the help of a strainer which was considered as a dusty panel and another was kept free from iron ore dust i.e. clean. Thereafter, at every one-minute interval the surface temperatures 
of panels (i.e. clean and dusty) were recorded, using pyrometer, till it reaches maximum permissible surface temperature $\left(83^{\circ} \mathrm{C}\right)$. This procedure was repeated for another two trials, i.e., by distributing $5 \mathrm{gm}$ and $8 \mathrm{gm}$ dust on the dusty panel.

The recorded surface temperature of clean and dusty PV panels with respect to time for iron ore dust deposition of $3 \mathrm{gm}$ is presented in Figure 4. As shown in Figure 4, the surface temperature of dusty panel is higher than the clean panel at every measured interval. This is mainly due to the current mismatch phenomena experienced by the dusty panel compared to clean panel. Moreover, the accumulated dust particles on the panel surface covers the cells of the panel completely or partially, which promotes the reverse biasing of the shaded cell. The reverse biasing of shaded cells enhances the surface temperature of PV panel under dusty condition [17]. The variation in the panel surface temperature due to different mass of dust deposition is illustrated in Figure 5. As depicted in Figure 5, the increase in panel surface temperature depends on the amount of deposition of dust particles on the panel surface. As the amount dust on the panel surface increases the panel surface temperature also increases with respect to clean panel under the same working condition. Moreover, the increase in PV panel surface temperature reduces Voc more significantly than the Isc of the panel [18].

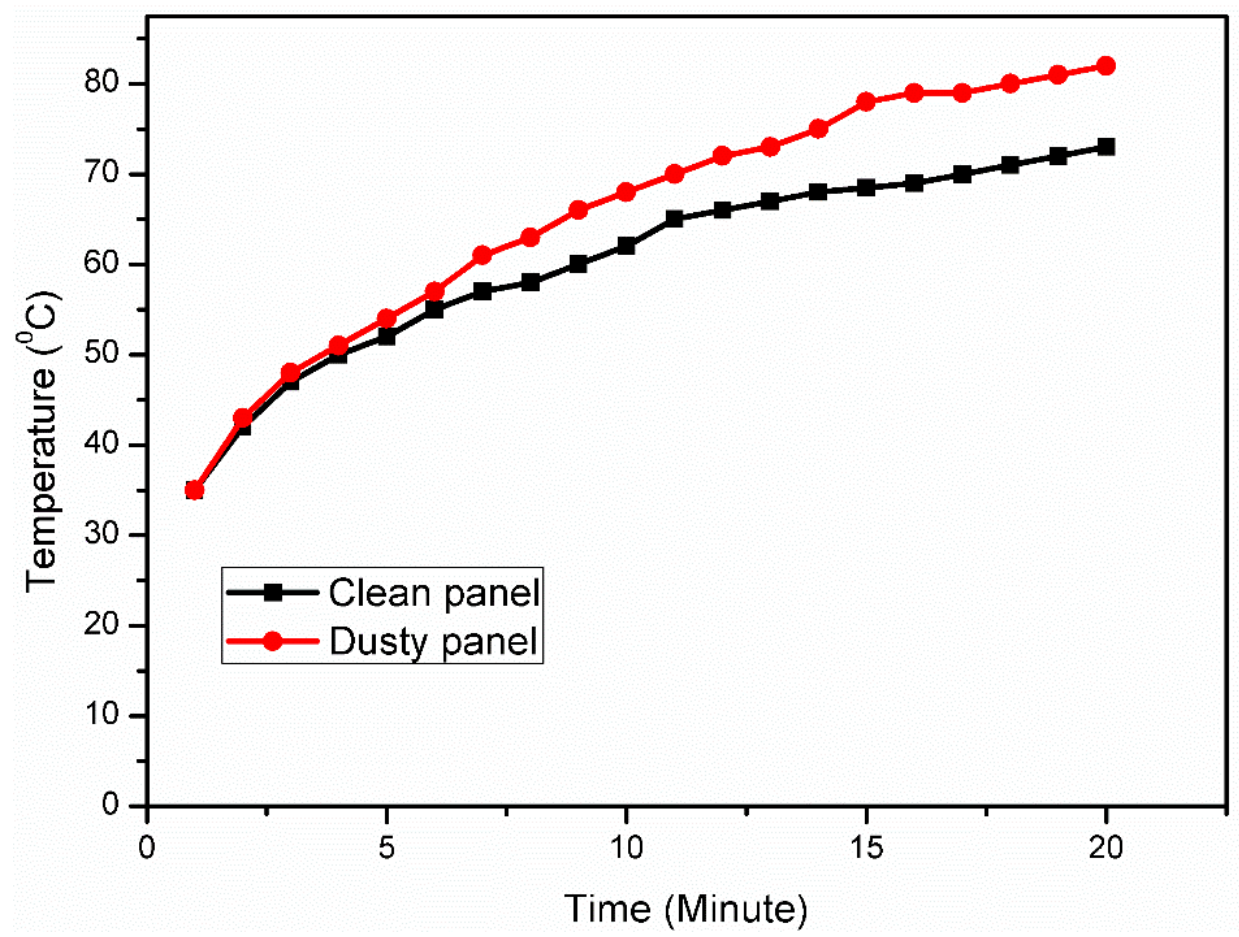

Figure 4: Temperature of cleaned and dusty PV panel with reference to time 


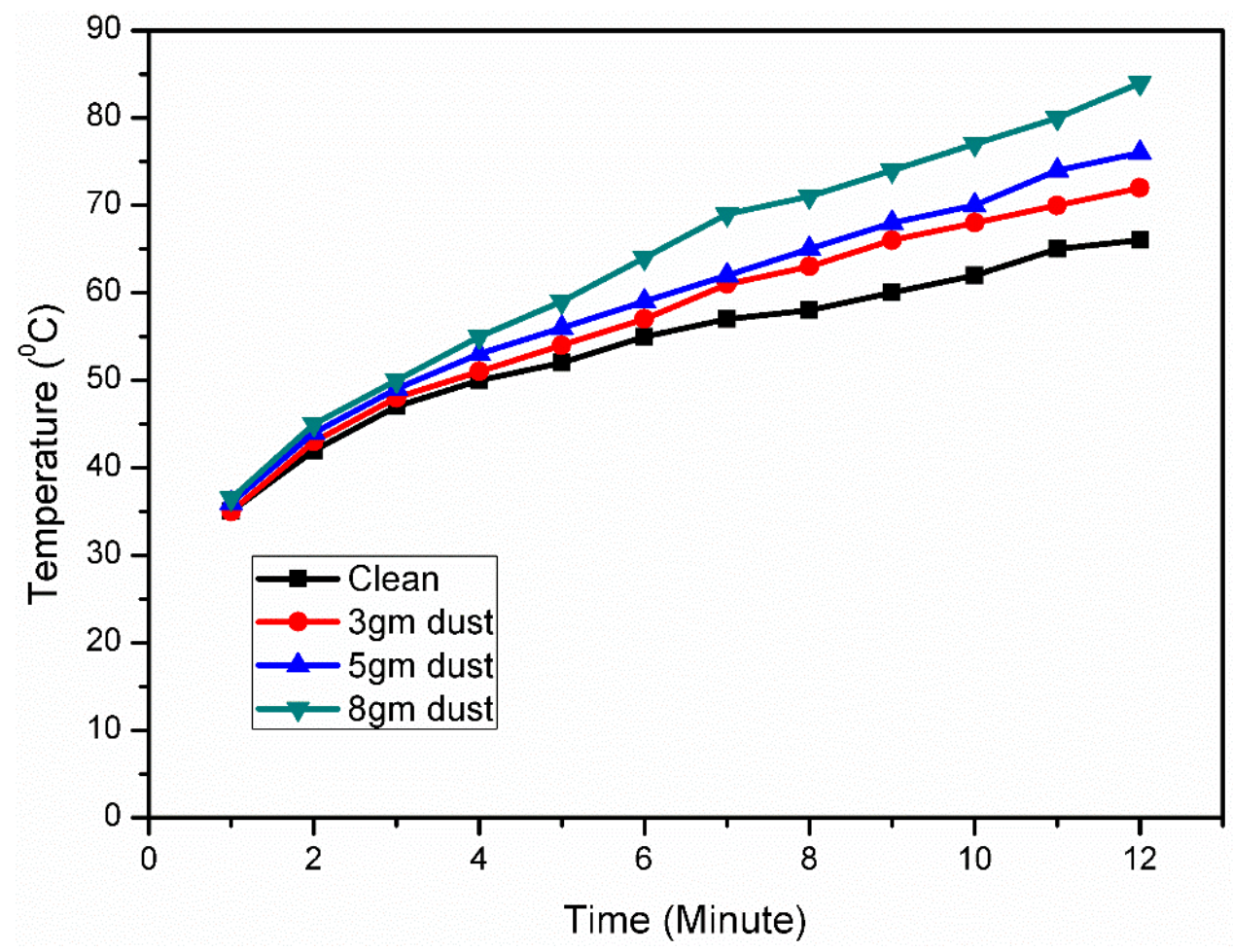

Figure 5: Temperature of PV panel under different surface condition with reference to time

\section{Conclusions}

Solar PV power could be a best alternative for the generation of electrical power in remote areas, particularly in locations where access of power is arduous, such as in mining areas, deserts, hill top etc. This paper demonstrates the influence of dust deposition on PV panel performance and its surface temperature. The reduction in Isc and Voc is respectively 0 to $30.56 \%$ and 0 to $3.24 \%$ for 0 to $11 \mathrm{gm}$ of dust deposition on the panel surface. The Isc and Pmax of the panel shows a negative relation with the amount of dust accumulation on module surface. The reduction in Pmax is up to $40 \%$, which is much significant. Moreover, this study also persuades that the surface temperature of dusty panel is higher than the clean panel under the same working conditions. This rise in panel surface temperature depends on the amount of dust deposition on its surface. Hence, this study demonstrates that a complete cleaning action of dust from PV panel surface and its cooling at regular interval must be ensured to improve the efficiency of solar energy module/system.

\section{References}

[1] Nehrir, M. H., Wang, C., Strunz, K., Aki, H., Ramakumar, R., Bing, J., ... \& Salameh, Z. (2011). A review of hybrid renewable/alternative energy systems for electric power generation: Configurations, control, and applications. IEEE Transactions on Sustainable Energy, 2(4), 392-403.

[2] Ozturk, I., Aslan, A., \& Kalyoncu, H. (2010). Energy consumption and economic growth relationship: Evidence from panel data for low and middle income countries. Energy Policy, 38(8), 4422-4428.

[3]Kabir, E., Kumar, P., Kumar, S., Adelodun, A. A., \& Kim, K. H. (2018). Solar energy: Potential and future prospects. Renewable and Sustainable Energy Reviews, 82, 894-900. 
[4] Mekhilef, S., Saidur, R., \& Safari, A. (2011). A review on solar energy use in industries. Renewable and Sustainable Energy Reviews, 15(4), 1777-1790.

[5] Dincer, F. (2011). The analysis on photovoltaic electricity generation status, potential and policies of the leading countries in solar energy. Renewable and Sustainable Energy Reviews, 15(1), 713-720.

[6] Saidan, M., Albaali, A. G., Alasis, E., \& Kaldellis, J. K. (2016). Experimental study on the effect of dust deposition on solar photovoltaic panels in desert environment. Renewable Energy, 92, 499-505.

[7] Adinoyi, M. J., \& Said, S. A. (2013). Effect of dust accumulation on the power outputs of solar photovoltaic modules. Renewable energy, 60, 633-636.

[8] El-Shobokshy, M. S., Mujahid, A., \& Zakzouk, A. K. M. (1985). Effects of dust on the performance of concentrator photovoltaic cells. IEE Proceedings I (Solid-State and Electron Devices), 132(1), 5-8.

[9] Elminir, H. K., Ghitas, A. E., Hamid, R. H., El-Hussainy, F., Beheary, M. M., \& Abdel-Moneim, K. M. (2006). Effect of dust on the transparent cover of solar collectors. Energy conversion and management, 47(18-19), 3192-3203.

[10] Hee, J. Y., Kumar, L. V., Danner, A. J., Yang, H., \& Bhatia, C. S. (2012). The effect of dust on transmission and self-cleaning property of solar panels. Energy Procedia, 15, 421-427.

[11] Semaoui, S., Arab, A. H., Bacha, S., Zeraia, H., \& Boudjelthia, E. K. (2015). Sand effect on photovoltaic array efficiency in Algerian desert. In 2nd International Congress on Energy Efficiency and Energy Related Materials (ENEFM2014) (pp. 85-90). Springer, Cham.

[12] Touati, F. A., Al-Hitmi, M. A., \& Bouchech, H. J. (2013). Study of the effects of dust, relative humidity, and temperature on solar PV performance in Doha: comparison between monocrystalline and amorphous PVS. International journal of green energy, 10(7), 680-689.

[13] E. Skoplaki and J. A. Palyvos, "On the temperature dependence of photovoltaic module electrical performance: A review of efficiency/power correlations," Sol. Energy, vol. 83, no. 5, pp. 614-624, 2009.

[14] Mahfoud, A., Mekhilef, S., \& Djahli, F. (2015). Effect of temperature on the GaInP/GaAs tandem solar cell performances. International Journal of Renewable Energy Research (IJRER), 5(2), 629-634.

[15] S. Krauter, “Increased electrical yield via water flow over the front of photovoltaic panels, ” Sol. Energy Mater. Sol. Cells, vol. 82, no. 1, pp. 131-137, 2004.

[16] Schwingshackl, C., Petitta, M., Wagner, J. E., Belluardo, G., Moser, D., Castelli, M., ... \& Tetzlaff, A. (2013). Wind effect on PV module temperature: Analysis of different techniques for an accurate estimation. Energy Procedia, 40, 77-86.

[17] Zegaoui, A., Petit, P., Aillerie, M., Sawicki, J. P., Belarbi, A. W., Krachai, M. D., \& Charles, J. P. (2011). Photovoltaic cell/panel/array characterizations and modeling considering both reverse and direct modes. Energy Procedia, 6, 695-703.

[18] Berginc, M., Krašovec, U. O., Jankovec, M., \& Topič, M. (2007). The effect of temperature on the performance of dye-sensitized solar cells based on a propyl-methyl-imidazolium iodide electrolyte. Solar energy materials and solar cells, 91(9), 821-828. 